\title{
Growth and Physiological Response of Jatropha Interspecific Hybrid (Jatropha curcas x J. integerrima) under Salt Stress
}

\author{
Dhimas Handhi Putranto ${ }^{1,2}$, Teerawat Tongkra², Cattleya Chutteang ${ }^{2}$, Weeraphan Sridokchan ${ }^{2 *}$ \\ ${ }^{1}$ Department of Agronomy, Faculty of Agriculture, Jember University, J1. Kalimantan II, Jember, East Java, 68121, Indonesia \\ ${ }^{2}$ Department of Agronomy, Faculty of Agriculture at Kamphaeng Saen, Kasetsart University, Nakhon Pathom, 73140, Thailand
}

*E-mail: agrwps@ku.ac.th

\begin{abstract}
Interspecific hybrid of Jatropha curcas $\mathbf{x} J$. integerrima is expected to answer the low oil yield problem of Jatropha (Jatropha curcas L.). However, as a novel invention, research concerning on Jatropha interspecific hybrid is still limited especially in the aspect of its adaptability to unfavorable environment such as salt stress condition. It is interesting to know how Jatropha interspecific hybrid responses to salt stress condition due to the moderate salt tolerance ability of its mother plant (J. curcas L.). The objectives of this study were to compare the growth and physiological response of interspecific hybrid and non-hybrid Jatropha under salt stress. Three varieties of both interspecific hybrid and non-hybrid Jatropha seedling were exposed with 3 levels of sodium chloride treatment in Hoagland media solution which are 2.0 (control), 8.0, and $16.0 \mathrm{dS} \mathrm{m}^{-1}$ for 7 weeks. The parameters measured include plant height, number of leaves, shoot dry weight, specific leaf area, chlorophyll content (SPAD Index), leaf water potential, and leaf solute concentration. V2 (interspecific hybrid) showed the highest potential as moderate salt tolerant variety among experimental Jatropha varieties due to its increasing trend of leaf number, dry weight, and total leaf area at moderate salinity level $\left(8 \mathrm{dS} \mathrm{m}^{-1}\right)$. KUBP 35 and KUBP 40 showed the best growth performance under salt stress among experimental Jatropha varieties, but its potential to be moderate salt tolerant variety was still lower than $\mathrm{V} 2$ variety. The solute concentration, osmotic potential, and turgor potential of both interspecific hybrid (V2) and non-hybrid variety (KUBP 35 and KUBP 40) showed an increasing pattern which could be implied as an adaptive response to salt stress. This study has showed that Jatropha interspecific hybrid might have an adaptive physiological response to salt stress and could be considered as potential moderate salt tolerant variety under salt stress.
\end{abstract}

Keywords — osmotic adjustment; salt tolerance; solute concentration; SPAD; sustainable energy.

\section{INTRODUCTION}

Biofuel as renewable energy resource is predicted to have more important role in the future. It is predicted that global biofuel consumption will increase from 1.3 mboe d $^{-1}$ in 2011 to $4.1 \mathrm{mboe} \mathrm{d}^{-1}$ in 2035 [9]. Jatropha (Jatropha curcas L.), an oil bearing species, has been widely known as source of biodiesel and predicted to be the most potential biofuel resource in the future. However, this plant still has some unfavorable agronomic traits for industrial purpose such as low oil yield especially compared to oil palm.

Jatropha (J. curcas L.) is known to have an ability to grow in saline soil and classified as moderate salt tolerance plant which can grow and produce seed in the saline condition up to $4 \mathrm{dS} \mathrm{m}^{-1}$ [5]. Jatropha has some mechanisms to adapt with salt stress. First, Jatropha can induce antioxidant enzyme activity like peroxidase, superoxide dismutase, or catalase which can protect plant from potentially cytotoxic reactive oxygen species (ROS). which are formed during water deficit condition caused by salt stress [22]. Second, Jatropha can accumulate compatible solutes (osmolytes) like proline, total soluble sugars, and total soluble protein to adapt with salt stress [4]. Third, as the primitive response mechanism during water deficit condition, Jatropha can reduce its transpiration rate during salt stress by stomatal closure or reducing leaf growth which will reduce specific leaf area for avoiding water loss.

Having some favorable traits including higher oil yield, interspecific hybrid of $J$. curcas $\mathrm{x} J$. integerrima is expected to be a better alternative variety of Jatropha. However, as a novel invention, research concerning on Jatropha interspecific hybrid is still limited especially in the aspect of its adaptability to unfavorable environment such as salt stress condition. It is interesting to know how the Jatropha interspecific hybrid response to saline condition since its mother plant ( $J$. curcas L.) is known to be moderate tolerant to salt stress. The objectives of this study was to compare the growth and physiological response of interspecific hybrid and non-hybrid Jatropha under salt stress. 


\section{MATERIAL AND METHODS}

\section{A. Plant Material}

Six varieties of Jatropha cuttings (supported by KUBiodiesel Project, Thailand) consisting of 2 different kinds of Jatropha plant which are Jatropha curcas L. (3 varieties) and interspecific hybrid of J. curcas x J. integerrima (3 varieties) were used as plant material. The experimental cuttings were prepared from 1 year old Jatropha plant grown in the Land Development Department at Nakhon Pathom, Kamphaeng Saen District, Nakhon Pathom Province, Thailand. The cuttings were prepared in the nursery for 10 weeks and then hardened for 2 weeks before starting the treatment by gradually adding $\mathrm{NaCl}$ every 3 days until reach particular concentration.

\section{B. Experimental Design}

Thirty three cuttings with 12 inch height and similar diameter size in each variety were selected for the treatment. The experiment was conducted on hydroponic culture at greenhouse of Department of Agronomy, Faculty of Agriculture at Kamphaeng Saen, Kasetsart University, Nakhon Pathom, Thailand from April $2^{\text {nd }}$ to May $21^{\text {st }}, 2014$. Factorial in complete randomized design (CRD) with 4 replications was used in this experiment. Three plants were used and sampled in each replication. Factor A was the variety of Jatropha which are interspecific hybrid variety (V1, V2, V4) and non-hybrid variety (India, KUBP 35, KUBP 40). Factor B was the level of saline stress in Hoagland nurient adjusted with $\mathrm{NaCl}$ which has Electrical Conductivity (EC) level 2.0 (control), 8.0, and $16.0 \mathrm{dS} \mathrm{m}^{-1}$.

\section{Measurements}

Parameters measured weekly throughout the experiment period include plant height and number of mature leaves, while specific leaf area (portable LI-3000A leaf area meter) and SPAD index (SPAD-50 Minolta Inc. Japan) were measured every 2 weeks. Physiological parameters measured include specific leaf area, leaf water potential $(\Psi \mathrm{t})$, solute concentration (Cs), osmotic potential $(\Psi \pi)$, and leaf turgor potential $(\Psi \mathrm{p})$. Those parameters were measured at week $6^{\text {th }}$ of the experiment by following the previous study of Chaiwut (2010) [2]. Physiological parameter measurement was done to three varieties which are V2 (interspecific hybrid), KUBP 35, and KUBP 40. Leaf water potential was measured with a pressure chamber using technique described by Turner (1981) [19]. Leaf water potential ( $\Psi \mathrm{t})$ was measured during predawn (4.00 am - 5.30 am) in leaf number 5 from the top. Solute concentration (Cs) was measured from the same leaves used in leaf water potential measurement by using Vapor Pressure Osmometer (Vapro 5520, Wescor Inc., USA). Osmotic potential $(\Psi \pi)$ was calculated as -RTCs, where R is gas constant $8.3143 \times 10^{-3} \mathrm{~m}^{3}$ $\mathrm{kPa} \mathrm{mol}^{-1} \mathrm{~K}^{-1}, \mathrm{~T}$ is absolute temperature. Turgor potential was calculated as $\Psi \mathrm{t}=\Psi \pi+\Psi \mathrm{p}$. Two way factorial ANOVA and Least Significant Difference (LSD) test were used as the method for mean comparison by using $\mathrm{R}$ stat program ver 2.13.1

\section{RESULT AND DISCUSSION}

\section{A. Growth Performance of Jatropha Interspecific Hybrid and Non-Hybrid under Salt Stress}

Parameters measured as the growth characteristics include number of leaves, relative growth rate (plant height), relative chlorophyll content (SPAD index), and shoot dry weight.

1. Number of Leaves

Statistical analysis showed that after 7 weeks salt stress exposure, $\mathrm{NaCl}$ and cultivar factors showed a significant effect to the leaf number of experimental Jatropha varieties, while interaction of both $\mathrm{NaCl}$ and cultivar factors showed a non-significant effect to the leaf number of experimental Jatropha varieties. $\mathrm{NaCl}$ caused a significant reduction of leaf number of all experimental Jatropha varieties at high salinity level $\left(16 \mathrm{dS} \mathrm{m}^{-1}\right)$ (Table I). Leaf number of all Jatropha varieties showed a non-significant difference at moderate salinity level $\left(8 \mathrm{dS} \mathrm{m}^{-1}\right)$, but showed a significant decrease at high salinity level $\left(16 \mathrm{dS} \mathrm{m}^{-1}\right)$. Overall, the interspecific hybrid varieties showed a lower total leaf number compared to the non-hybrid varieties both at moderate $\left(8 \mathrm{dS} \mathrm{m}^{-1}\right)$ and high salinity level $\left(16 \mathrm{dS} \mathrm{m}^{-1}\right)$. Only V2 (interspecific hybrid) showed a slight increase of leaf number at $8 \mathrm{dS} \mathrm{m}^{-1}$ but then decrease at $16 \mathrm{dS} \mathrm{m}^{-1}$, while KUBP 35 and KUBP 40 showed the highest leaf number both at high $\left(8 \mathrm{dS} \mathrm{m}^{-1}\right)$ and moderate $\left(16 \mathrm{dS} \mathrm{m}^{-1}\right)$ salinity level. Eventhough the non-significant difference between control and $8 \mathrm{dS} \mathrm{m}^{-1}$, this result showed that $\mathrm{V} 2$ could have a higher potential as salt tolerant variety than KUBP 35 and KUBP 40 and the highest among experimental Jatropha varieties based on number of leaves parameter.

TABLE I

NUMBER OF LEAVES OF JATROPHA INTERSPECIFIC HYBRID AND NON-HYBRID VARIETIES AFTER 7 WEEKS SALT STRESS EXPOSURE

\begin{tabular}{|c|c|c|c|c|}
\hline \multirow{3}{*}{$\begin{array}{l}\text { Jatropha } \\
\text { Variety }\end{array}$} & \multicolumn{4}{|c|}{ Number of Leaves } \\
\hline & \multicolumn{3}{|c|}{ After 7 weeks exposure } & \multirow{2}{*}{ Mean } \\
\hline & Control & $8 \mathrm{dS} \mathrm{m}^{-1}$ & $16 \mathrm{dS} \mathrm{m}^{-1}$ & \\
\hline V1 & 23.25 & 18.79 & 9.90 & $17.31 \mathrm{~cd}$ \\
\hline $\mathrm{V} 2$ & 19.14 & 24.04 & 9.52 & $17.57 \mathrm{bcd}$ \\
\hline V4 & 10.00 & 7.50 & 4.67 & $7.39 \mathrm{~d}$ \\
\hline India & 25.83 & 24.42 & 11.75 & $20.67 \mathrm{bc}$ \\
\hline KUBP 35 & 52.46 & 36.25 & 19.83 & 36.18 a \\
\hline KUBP 40 & 40.44 & 26.67 & 23.92 & $30.34 \mathrm{ab}$ \\
\hline Mean $^{2}$ & $28.52 \mathrm{a}$ & $22.94 \mathrm{a}$ & $13.27 \mathrm{~b}$ & \\
\hline $\begin{array}{c}\text { F-test } \\
\text { cultivar }^{1}\end{array}$ & & & $* * *$ & \\
\hline F-test $\mathrm{NaCl}^{2}$ & & & $* * *$ & \\
\hline cultivar $\times \mathrm{NaCl}$ & & & ns & \\
\hline$\%$ C.V. & & & 39.76 & \\
\hline
\end{tabular}

Decreasing trend of leaf number at high level of salinity $\left(16 \mathrm{dS} \mathrm{m}^{-1}\right)$ is an evident that salt stress could reduce the growth of plant indicated by reduction of its leaf number. This result has been confirmed by the results of previous researches in barley [10] and cowpea [17], which showed 
that the treatment of sodium chloride reduced the number of leaves compared with control plants. Inhibition of the formation of leaf primodia under salinity stress could be the probable reason for low leaf number [1]. The decrease of leaf numbers may be due to the accumulation of sodium chloride in the cell walls and cytoplasm of the older leaves. At the same time, their vacuole sap cannot accumulate more salt and, thereby decreases the concentration of salt inside the cells, which ultimately leads to their quick death and cut down [18].

In case of leaf number, V2 could be suspected to have a moderate salt tolerance ability because it showed a slight increase of leaf number under moderate salinity level ( $8 \mathrm{dS}$ $\mathrm{m}^{-1}$ ). However, leaf number parameter alone is not enough to determine the salt tolerability of plant. There are other growth characteristics that can refer to the plant health and photosynthesis rate of plant. Dry biomass (dry weight) is one of the best references to predict the effect of stress on plant due to its strong relation to the atmospheric carbon assimilation via photosynthesis.

\section{Relative Growth Rate (Plant Height)}

TABLE II

RELATIVE GROWTH RATE OF JATROPHA INTERSPECIFIC HYBRID AND NONHYBRID VARIETIES AFTER 7 WEEKS SALT STRESS EXPOSURE

\begin{tabular}{|c|c|c|c|c|}
\hline \multirow{3}{*}{$\begin{array}{l}\text { Jatropha } \\
\text { Variety }\end{array}$} & \multicolumn{4}{|c|}{ Relative Growth Rate (cm/week) } \\
\hline & \multicolumn{3}{|c|}{ After 7 weeks exposure } & \multirow{2}{*}{ Mean } \\
\hline & Control & $8 \mathrm{dS} \mathrm{m}^{-1}$ & $16 \mathrm{dS} \mathrm{m}^{-1}$ & \\
\hline V1 & 0.61 & 0.43 & 0.35 & 0.46 \\
\hline V2 & 0.25 & 0.32 & 0.14 & 0.24 \\
\hline V4 & 0.40 & 0.56 & 0.35 & 0.43 \\
\hline India & 0.54 & 0.52 & 0.46 & 0.50 \\
\hline KUBP 35 & 1.30 & 0.35 & 0.50 & 0.72 \\
\hline KUBP 40 & 0.25 & 0.44 & 0.20 & 0.30 \\
\hline Mean & 0.56 & 0.44 & 0.33 & \\
\hline F-test cultivar ${ }^{1}$ & \multicolumn{4}{|c|}{ ns } \\
\hline F-test $\mathrm{NaCl}$ & \multicolumn{4}{|c|}{ ns } \\
\hline cultivar $\times \mathrm{NaCl}$ & \multicolumn{4}{|c|}{ ns } \\
\hline$\%$ C.V. & \multicolumn{4}{|c|}{47.90} \\
\hline
\end{tabular}

All of the experimental plant could be classified as the halophyte plant due to the positive relative growth rate after 7 weeks salt stress exposure. Statistical analysis showed that $\mathrm{NaCl}$, cultivar, and interaction of both $\mathrm{NaCl}$ and cultivar factor did not cause a significant difference of plant relative growth rate (plant height) among experimental Jatropha varieties. The high \% C.V. showed by relative growth rate data could be because this experiment used 2 completely different varieties (interspecific hybrid and non-hybrid Jatropha) which has different genetic background. However, there are three varieties V2, V4 nd KUBP 40 which showed the non-significant increase of relative growth rate at moderate salinity level $8 \mathrm{dS} \mathrm{m}^{-1}$ (Table II). It is quite interesting that both of V2 and KUBP 40 also showed the lowest relative growth rate in the control condition $(0.25$ $\mathrm{cm} /$ week). The slow growth rate character is one of the good parameter of high salt tolerant plant [6].

\section{Total Leaf Area (Plant Height)}

After 6 weeks salt stress exposure, statistical analysis showed that $\mathrm{NaCl}$, cultivar, and the interaction of both factors showed a significant effect to the total leaf area of all experimental Jatropha varieties. $\mathrm{NaCl}$ caused a significant reduction of total leaf area of all experimental Jatropha varieties especially at high salinity level $\left(16 \mathrm{dS} \mathrm{m}^{-1}\right)$ (Table III). Only V2 showed a slight increase of total leaf area at 8 $\mathrm{dS} \mathrm{m}{ }^{-1}$, but then showed a decrease at $16 \mathrm{dS} \mathrm{m}^{-1}$. KUBP 35 and KUBP 40 showed the highest total leaf area both at moderate $\left(8 \mathrm{dS} \mathrm{m}^{-1}\right)$ and high salinity level $\left(16 \mathrm{dS} \mathrm{m}^{-1}\right)$, while V4 showed the lowest leaf number both at at moderate $\left(8 \mathrm{dS} \mathrm{m}^{-1}\right)$ and high salinity level $\left(16 \mathrm{dS} \mathrm{m}^{-1}\right)$. Overall, the interspecific hybrid varieties showed a lower total leaf area compared to the non-hybrid varieties both at moderate and high salinity level. From the total leaf area data, it appeared that only V2 was less affected by salt stress especially at moderate level of salinity $\left(8 \mathrm{dS} \mathrm{m}^{-1}\right)$ when compare with the control treatment, eventhough its total leaf area was less than KUBP 35 and KUBP 40, respectively.

TABLE III

TOTAL LEAF AREA OF JATROPHA INTERSPECIFIC HYBRID AND NON-HYBRID VARIETIES AFTER 6 WEEKS SALT STRESS EXPOSURE

\begin{tabular}{|c|c|c|c|c|}
\hline \multirow{3}{*}{$\begin{array}{c}\text { Jatropha } \\
\text { Variety }\end{array}$} & \multicolumn{4}{|c|}{ Total Leaf Area $\left(\mathrm{cm}^{2}\right)$} \\
\hline & \multicolumn{3}{|c|}{ After 6 weeks exposure } & \multirow{2}{*}{$\operatorname{Mean}^{1}$} \\
\hline & Control & $8 \mathrm{dS} \mathrm{m}^{-1}$ & $16 \mathrm{dS} \mathrm{m}^{-1}$ & \\
\hline V1 & 3868.80 & 2430.02 & 1589.95 & $2629.59 \mathrm{~b}$ \\
\hline $\mathrm{V} 2$ & 2234.42 & 2961.78 & 1210.74 & $2135.65 \mathrm{bc}$ \\
\hline V4 & 1012.09 & 298.48 & 286.16 & $532.24 \mathrm{c}$ \\
\hline India & 2760.92 & 1856.89 & 1347.47 & $1988.43 \mathrm{bc}$ \\
\hline KUBP 35 & 7343.85 & 5369.56 & 2749.57 & 5154.33 a \\
\hline KUBP 40 & 5969.46 & 3169.59 & 3623.56 & $4254.20 \mathrm{a}$ \\
\hline Mean $^{2}$ & 3864.92 a & 2681.05 ab & $1801.24 \mathrm{~b}$ & \\
\hline F-test cultivar ${ }^{1}$ & \multicolumn{4}{|c|}{$* * *$} \\
\hline F-test $\mathrm{NaCl}^{2}$ & \multicolumn{4}{|c|}{$* * *$} \\
\hline cultivar $\times \mathrm{NaCl}$ & \multicolumn{4}{|c|}{$* *$} \\
\hline$\%$ C.V. & \multicolumn{4}{|c|}{41.78} \\
\hline
\end{tabular}

Leaf area represents a measure of plant growth, which can be affected by different stresses, including salt stress. Decreasing trend of total leaf area with increasing level of salinity especially at high salinity level $\left(16 \mathrm{dS} \mathrm{m}^{-1}\right)$ indicated that salt stress could inhibit the growth of Jatropha. This result agrees with the result of previous researches on oat [24] and sugar beet [12], which reported decrease of leaf area under salt stress. Decreasing trend of total leaf area at high salinity level $\left(16 \mathrm{dS} \mathrm{m}^{-1}\right)$ found in this study could be explained by the negative effect of salt on photosynthesis that leads to the reduction of leaf growth [20]

\section{Relative Chlorophyll Content (SPAD Index)}

After 6 weeks salt stress exposure, $\mathrm{NaCl}$ and interaction of $\mathrm{NaCl}$ and cultivar factor did not cause a significant change in plant relative chlorophyll content, but the varietal factor caused a significant difference of relative chlorophyll content among experimental Jatropha varieties. KUBP 35 
and V2 had the highest SPAD index (27.41 and 27.39 respectively) among experimental Jatropha varieties, while V4 showed the lowest SPAD index (24.23) among experimental Jatropha varieties (Table IV). Overall, the interspecific hybrid varieties (V1, V2, V4) and non-hybrid varieties (India, KUBP 35, KUBP 40) showed a relatively same SPAD index after 6 weeks salt stress exposure.

Non-significant difference showed by all of the experimental Jatropha varieties as the effect of salt stress is an indication that both interspecific hybrid and non-hybrid varieties could be suspected to have a moderate salt tolerance ability. Salt accumulation in leaves often induces chlorophyll decomposition [11]. Hence, chlorophyll content is used as one of the salt tolerance characteristic of plant [8]. Non-significant difference of chlorophyll content during salt stress indicated the ability of plant to adapt with salt stress because delay of chlorophyll degradation during salt stress is one of the characteristics of salt tolerant species [3].

TABLE IV

RELATIVE CHLOROPHYLL CONTENT (SPAD INDEX) OF JATROPHA INTERSPECIFIC HYBRID AND NON-HYBRID VARIETIES AFTER 6 WEEKS SALT STRESS EXPOSURE

\begin{tabular}{|c|c|c|c|c|}
\hline \multirow{3}{*}{$\begin{array}{l}\text { Jatropha } \\
\text { Variety }\end{array}$} & \multicolumn{4}{|c|}{ SPAD Index } \\
\hline & \multicolumn{3}{|c|}{ After 6 weeks exposure } & \multirow{2}{*}{$\operatorname{Mean}^{1}$} \\
\hline & Control & $8 \mathrm{dS} \mathrm{m}^{-1}$ & $16 \mathrm{dS} \mathrm{m}^{-1}$ & \\
\hline V1 & 27.07 & 26.96 & 24.21 & 26.08 a \\
\hline V2 & 27.77 & 26.70 & 27.70 & 27.39 a \\
\hline V4 & 20.75 & 22.88 & 24.65 & $22.76 \mathrm{~b}$ \\
\hline India & 28.12 & 23.72 & 22.66 & $24.83 \mathrm{ab}$ \\
\hline KUBP 35 & 30.65 & 28.01 & 23.57 & 27.41 a \\
\hline KUBP 40 & 23.59 & 22.21 & 22.53 & $25.34 \mathrm{ab}$ \\
\hline Mean & 26.32 & 25.08 & 24.22 & \\
\hline F-test cultivar ${ }^{1}$ & \multicolumn{4}{|c|}{ * } \\
\hline F-test $\mathrm{NaCl}$ & \multicolumn{4}{|c|}{$\mathrm{ns}$} \\
\hline cultivar $\times \mathrm{NaCl}$ & \multicolumn{4}{|c|}{ ns } \\
\hline$\%$ C.V. & \multicolumn{4}{|c|}{15.52} \\
\hline
\end{tabular}

${ }^{\top}$ Means followed with different letter within column are significantly different by LSD test * Means are significantly different at $\mathrm{P}<0.05$

\section{Shoot Dry Weight}

Shoot dry weight of interspecific hybrid varieties, except V4, were significantly increased at moderate level of salinity $\left(8 \mathrm{dS} \mathrm{m}^{-1}\right)$, but they were significantly decreased at high

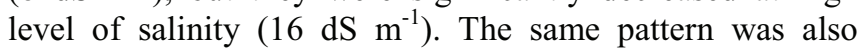
shown in the Jatropha non-hybrid varieties, except India. Those pattern showed that some varieties (V1, V2, KUBP 35, and KUBP 40) could be suspected to have a moderate salt tolerance ability indicated by increasing dry weight at moderate level of salinity. The pattern of increasing dry biomass at higher level of salinity was also shown in some plants which is considered as salt tolerant plant like Alhagi pseudoalhagi [16], Halophyrum mucronatum [17], and Salicornia rubria [18] which showed increasing biomass with the increasing of salinity at particular level and decreasing biomass at further salinity level. Decrease of dry weight at $16 \mathrm{dS} \mathrm{m}^{-1}$ in this result indicated that $8 \mathrm{dS} \mathrm{m}^{-1}$ is the tolerability level of salt stress for the experimental
Jatropha salt tolerance varieties: V1, V2, KUBP 35, and KUBP 40.

Result of growth parameter measurement showed that Jatropha varieties (interspecific hybrid and non-hybrid) showed inhibition of growth under salt stress. The inhibition of growth of Jatropha when exposed to high salt $(\mathrm{NaCl})$ concentration could be attributed to three specific growth constraints, which are: (i) drastic changes in the plant water status caused by osmotic effect of salinity, (ii) increase of the ion toxicity concentration, and (iii) the nutritional imbalance caused by alteration in the absorption of essential nutrients [15]. Dry biomass reduction pattern could be caused by reduction of $\mathrm{CO}_{2}$ availability caused by stomatal closure which can induce a further biomass reduction through photosynthesis suppression [8].

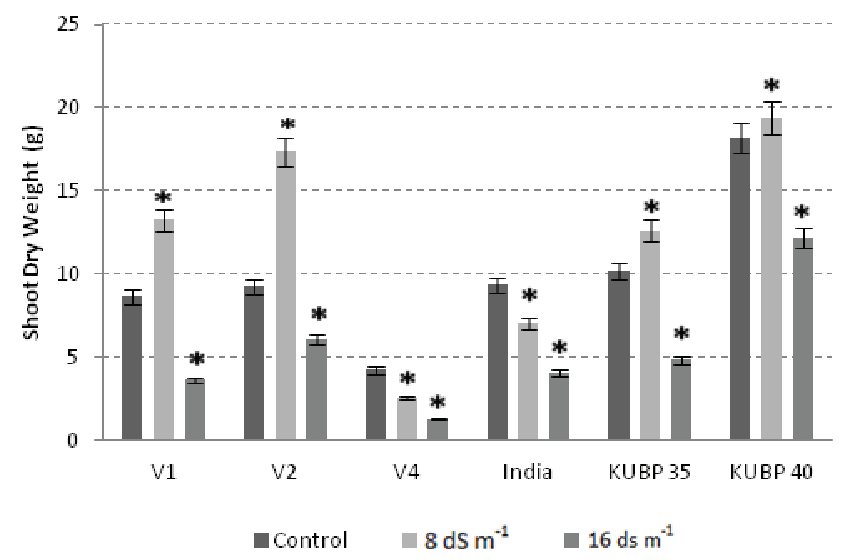

Fig. 1 Shoot Dry Biomass of Jatropha Interspecific Hybrid and Non-Hybrid Varieties under Salt Stress (after 7 weeks exposure)

The growth measurement result indicated that both Jatropha interspecific hybrid and non-hybrid represented by some of its varieties could be suspected to have a moderate salt tolerance ability. V2 (interspecific hybrid) could be suspected as variety with the highest potential to be moderate salt tolerant variety among experimental Jatropha varieties. It was confirmed by the increasing trend of leaf number, total leaf area, and dry weight of V2 at moderate salinity level $\left(8 \mathrm{dS} \mathrm{m}^{-1}\right)$. KUBP 35 and KUBP 40 also could be suspected as moderate salt tolerant variety eventhough they showed a negative leaf number growth trend at moderate salinity level which makes it considered to have lower potential as moderate salt tolerant variety than V2. That conclusion based on some arguments: (1) Eventhough, leaf number of KUBP 35 and KUBP 40 were significantly decreased at $8 \mathrm{dS} \mathrm{m}^{-1}$, their shoot weight were significantly increased after 7 weeks exposure. In addition, KUBP 40 showed the highest shoot weight in the salt stress condition both at 8 and $16 \mathrm{dS} \mathrm{m}^{-1}$ (Fig 1). In Jatropha, leaf number is not always linearly correlated with the biomass of plant. Nyi nyi et al. (2012) reported that the photosynthesis efficiency in the normal Jatropha leaf also depends on the chlorophyll content and can be predicted by using the SPAD index. Maximum quantum efficiency $(\mathrm{Fv} / \mathrm{Fm})$ is an important parameter to measure the effect of stress on the photosynthesis rate which can be applied to screen the stress tolerant plant (data not shown) [21]. It explains why KUBP 35 and KUBP 40 showed an increase of shoot biomass at 8 
$\mathrm{dS} \mathrm{m}{ }^{-1}$ while their leaf number showed a decreasing trend. It is because KUBP 35 and KUBP 40 must have a high photosynthesis efficiency for the whole plant. (2) Based on our observation, the old leaf of non-hybrid Jatropha was senescent and fell down faster than the interspecific hybrid. A rapid fall down of leaves is one mechanism of plant to reduce the impact of $\mathrm{Na}^{+}$and $\mathrm{Cl}^{-}$toxicity in the whole plant which means that the non-hybrid Jatropha varieties showed an adaptive response to salt stress and explains why KUBP 35 and KUBP 40 showed a decreasing trend of leaf number under salt stress.

From these results, KUBP 35, KUBP 40 (non-hybrid) and V2 (interspecific hybrid) could be classified as moderate salt tolerant Jatropha variety. This conclusion was also confirmed by further salt stress experiment involving those three varieties at in-vitro condition. This result implied that those three varieties must have certain adaptation ability to salt stress in order to maintain their growth performance.
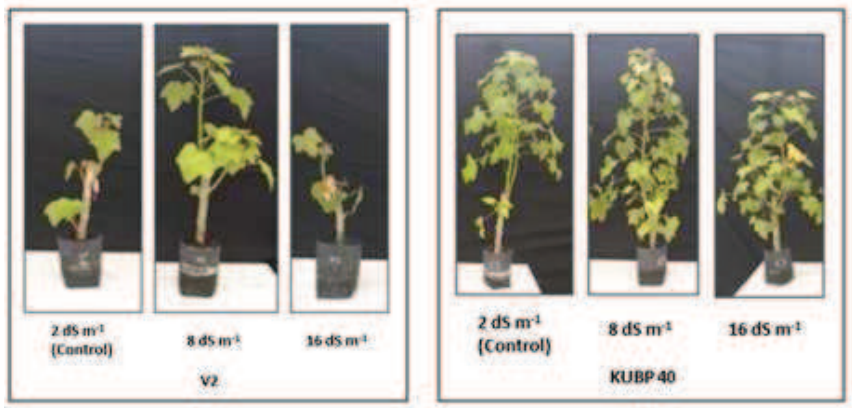

Fig. 2 Growth Comparison of V2 (Interspecific Hybrid) and KUBP 40 (Non-Hybrid) at Three Different Levels of Sodium Chloride $(\mathrm{NaCl})$ Concentration (After 7 weeks exposure)

\section{B. Physiological Response of Jatropha interspecific Hybrid and Non-Hybrid under Salt Stress Condition}

Physiological parameters measured include specific leaf area, leaf water potential $(\Psi \mathrm{t})$, solute concentration $(\mathrm{Cs})$, osmotic potential $(\Psi \pi)$, and leaf turgor potential $(\Psi p)$.

\section{Specific Leaf Area (SLA)}

Statistical analysis showed that after 6 weeks exposure, $\mathrm{NaCl}$, cultivar, and interaction of both $\mathrm{NaCl}$ and cultivar factor did not cause a significant difference of plant specific leaf area among experimental Jatropha varieties (Table V). Non-significant differences of specific leaf area among experimental Jatropha varieties is an indication that both Jatropha interspecific hybrid and non-hybrid variety could be suspected as moderate salt tolerant. However, we found that interspecific hybrid varieties, V2 and V4, showed the decrease of SLA at $8 \mathrm{dS} \mathrm{m}^{-1}$ when compare with the control. The SLA depression is one of the characteristic of salt tolerant plant. The high thickness of leaf, the less effect of drought and heat in the living leaf cell. This result agree with previous reserach in perennial halophyte plant Lycium barbarum which showed decrease of SLA under salt stress as part of its adaptive mechanism [23].
TABLE V

SPECIFIC LEAF AREA (SLA) OF JATROPHA INTERSPECIFIC HYBRID AND NONHYBRID VARIETIES AFTER 6 WEEKS SALT STRESS EXPOSURE

\begin{tabular}{|c|c|c|c|c|}
\hline \multirow{3}{*}{ Jatropha Variety } & \multicolumn{4}{|c|}{ Specific Leaf Area $\left(\mathrm{cm}^{2} / \mathrm{g}\right)$} \\
\hline & \multicolumn{3}{|c|}{ After 7 weeks exposure } & \multirow{2}{*}{ Mean } \\
\hline & Control & $8 \mathrm{dS} \mathrm{m}^{-1}$ & $16 \mathrm{dS} \mathrm{m}^{-1}$ & \\
\hline V1 & 132.95 & 166.15 & 206.78 & 168.63 \\
\hline $\mathrm{V} 2$ & 278.68 & 174.78 & 207.48 & 220.31 \\
\hline V4 & 315.35 & 190.35 & 181.38 & 229.03 \\
\hline India & 191.58 & 198.58 & 184.33 & 191.50 \\
\hline KUBP 35 & 151.88 & 195.43 & 197.30 & 181.54 \\
\hline KUBP 40 & 187.65 & 193.08 & 222.10 & 200.94 \\
\hline Mean & 209.68 & 186.40 & 199.90 & \\
\hline F-test cultivar & \multicolumn{4}{|c|}{$\mathrm{ns}$} \\
\hline F-test $\mathrm{NaCl}$ & \multicolumn{4}{|c|}{ ns } \\
\hline cultivar $\times \mathrm{NaCl}$ & \multicolumn{4}{|c|}{ ns } \\
\hline$\%$ C.V. & \multicolumn{4}{|c|}{50.06} \\
\hline
\end{tabular}

\section{Leaf-Water Relation}

In case of leaf water potential parameter, both Jatropha interspecific hybrid (V2) and non-hybrid (KUBP 35 and KUBP 40) showed a non-significant decrease result. But, in case of solute concentration (Cs), both interspecific hybrid and non-hybrid variety showed a significant increasing pattern with increasing level of salinity. KUBP 40 showed an increasing trend at every higher level of salinity, while V2 and KUBP 35 showed an increasing trend at $8 \mathrm{dS} \mathrm{m}^{-1}$ and decreasing trend at $16 \mathrm{dS} \mathrm{m}^{-1}$. Those pattern implied that KUBP 40 could have a higher salt tolerance ability than V2 and KUBP 35. However, pattern shown by V2 and KUBP 35 implied that those 2 varieties could also have an adaptive response to salt stress indicated by the increasing trend of solute concentration at moderate level of salinity $\left(8 \mathrm{dS} \mathrm{m}^{-1}\right)$.

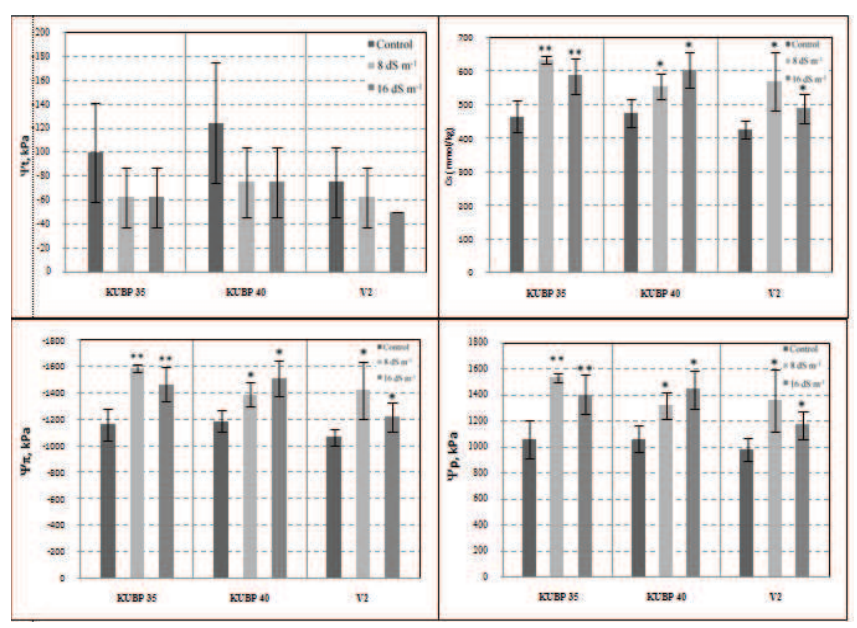

Fig. 3 Leaf Water Potential $(\Psi \mathrm{t})$, Solute Concentration (Cs), Osmotic Potential $(\Psi \pi)$, and Turgor Potential ( $\Psi$ p) of Jatropha Hybrid (V2) and Non-Hybrid varieties (KUBP 35 and KUBP 40) under Salt Stress Condition (after 7 weeks exposure)

Leaf solute concentration indicates whether a plant has an adaptive mechanism to salt stress or not. Increasing solute concentration during salt stress is an indication that a plant 
try to adapt with salt stress by accumulating compatible solutes which has main purpose to accomodate ionic balance in the vacuoles. In order to acomodate the ionic balance in the vacuoles, cytoplasm accumulates low-molecular-mass compounds termed compatible solutes. These compatible solutes include mainly proline, glycine betaine, soluble sugar, and polyols [22].

The solute concentration (Cs), osmotic potential $(\Psi \pi)$, and turgor potential $(\Psi \mathrm{p})$ measurement result showed an increasing pattern for each variety (Fig. 3). For KUBP 40, the increasing pattern of $\mathrm{Cs}, \Psi \pi$, and $\Psi \mathrm{p}$ is linier with increasing of salinity. While for KUBP 35 and V2, the Cs, $\Psi \pi$, and $\Psi \mathrm{p}$ only increase at $8 \mathrm{dS} \mathrm{m}^{-1}$ and then decrease at $16 \mathrm{dS} \mathrm{m}^{-1}$. It could be implied that for V2 and KUBP 35 the salt tolerability level was at $8 \mathrm{dS} \mathrm{m}^{-1}$, because at further level of salinity those varieties showed decreasing pattern which means decreasing of adaptive mechanism activity through accumulation of compatible solutes.

Results found in this study indicated that all of the varieties measured for physiological response which are V2, KUBP 35, and KUBP 40 showed an adaptative mechanism during salt stress condition. It is indicated by the significant increasing trend of Cs under salt stress. Increasing trend of Cs, $\Psi \pi$, and $\Psi \mathrm{p}$ indicated that those varieties has an ability to adapt with salt stress through accumulation of compatible solutes mechanism which has main purpose to maintain the the leaf water potential. A non-significant result in leaf water potential data could be because it is not yet significantly shown. However, from the data of $\mathrm{Cs}, \Psi \pi$, and $\Psi \mathrm{p}$, we could imply that there is an adaptation response shown by both Jatropha interspecific hybrid and non-hybrid variety under salt stress by accumulation of compatible solutes mechanism. The adaptive response shown by those varieties confirmed the growth performance result which suspected V2, KUBP 35 and 40 as moderate salt tolerant variety.

\section{CONCLUSIONS}

Overall, the growth of interspecific hybrid variety under salt stress mostly is lower than non-hybrid variety, but V2 (interspecific hybrid) could be considered to have higher potential as salt tolerant variety than KUBP 35 and 40 (nonhybrid variety) due to the increasing trend of its leaf number, dry weight, and total leaf area under moderate salinity level $\left(8 \mathrm{dS} \mathrm{m}^{-1}\right)$. The salt tolerant potential of $\mathrm{V} 2$ was confirmed by an adaptive physiological response mechanism to salt stress showed by V2, which was similar with the non-hybrid variety (KUBP 35 and KUBP 40).

\section{ACKNOWLEDGMENT}

The authors would like to thank KU-Biodiesel Project, Thailand for experimental plant materials and financial support for this research. We also would like to thank the Center for Agricultural Biotechnology (CAB), Kasetsart University for scientific instrument support to run this experiment.

\section{REFERENCES}

[1] Alamgir, A., and Ali, M. (2006). Effects of $\mathrm{NaCl}$ Salinity on Leaf Characters and Physiological Growth Attributes of Different Genotypes of Rice (Oryza sativa L.). Bangladesh J Bot, 35: 99-107.
[2] Chaiwut, N., W. Sridokchan, A. Kumlung, and A. Saimaneerat, 2010 Screening of Physic Nut (Jatropha curcas L.) for Salt Tolerance at Germination Stage. The $7^{\text {th }}$ KU-KPS Conference, 7-8 December, Kamphaeng Saen, Nakhon Pathom, Thailand.

[3] Cha-Um, S., Charoenpanich, A., Roytrakul, S., \& Kirdmanee, C. 2009. Sugar accumulation, photosynthesis and growth of two indica rice varieties in response to salt stress. Acta physiologiae plantarum, 31(3), 477-486.

[4] Chaves, M. M., Flexas, J., and Pinheiro, C. 2009. Photosynthesis under drought and salt stress: regulation mechanisms from whole plant to cell. Annals of botany, 103(4): 551-560.

[5] Díaz-López, L., Gimeno, V., Lidón, V., Simón, I., Martínez, V., \& García-Sánchez, F. 2012. The tolerance of Jatropha curcas seedlings to NaCl: An ecophysiological analysis. Plant Physiology and Biochemistry, 54: 34-42.

[6] Gorham, J. 1995. Mechanism of salt tolerance of halophytes. Halophytes and biosaline agriculture, 207-223.

[7] Hasegawa, P. M., Bressan, R. A., Zhu, J. K., Bohnert, H. J. 2000 Plant cellular and molecular responses to high salinity. Annual review of plant biology. 51(1): 463-499.

[8] Hishida, M., F. Ascencio, H. Fujiyama. A. Orduno-Cruz. T. Endo. J. A. Larrinaga-Mayoral. 2013. Differential Responses of Jatropha Species on Growth and Physiological Parameters to Salinity Stress at Seedling Plant Stage. Communication in Soil Science and Plant Analysis. 44: 2820-2829

[9] International Energy Agency. 2013. World Energy Outlook 2013 www.iea.org. OCDE/IEA.

[10] Iyengar, E., Patolia, J., and Kurian, T. 1977. Varietal Differences in Barley to Salinity. Zeitschrift für Pflanzenphysiologie, 84(4): 355361

[11] James, A., Rivelli, R., Munns, R., and Von Caemmerer, S. 2002. Factors Affecting $\mathrm{CO} 2$ Assimilation, Leaf Injury and Growth in SaltStressed Durum Wheat. Functional Plant Biology, 29(12): 13931403 .

[12] Jamil, M., Rehman, S., and Rha, E., 2007. Salinity Effect on Plant Growth, ps11 Photochemistry and Chlorophyll Content in Sugar Beet (Beta vulgaris L.) and Cabbage (Brassica oleracea capitata L.). Pak. J. Bot. 39(3): 753-760.

[13] Khan, M. A., Ungar, I. A., and Showalter, A. M. 1999. Effects of salinity on growth, ion content, and osmotic relations in Halopyrum mucronatum (L.) Stapf. Journal of Plant Nutrition, 22(1), 191-204.

[14] Khan, M. A., Gul, B., and Weber, D. J. 2001. Effect of salinity on the growth and ion content of Salicornia rubra. Communications in soil science and plant analysis, 32(17-18), 2965-2977

[15] Kumar, A., and Sharma, S. 2008. An evaluation of multipurpose oil seed crop for industrial uses (Jatropha curcas L.): A review. Industrial crops and products, 28(1), 1-10.

[16] Kurban, H., Saneoka, H., Nehira, K., Adilla, R., Premachandra, G. S., and Fujita, K. 1999. Effect of salinity on growth, photosynthesis and mineral composition in leguminous plant Alhagi pseudoalhagi (Bieb.). Soil science and plant nutrition, 45(4), 851-862.

[17] López-Aguilar, R., Orduño-Cruz, A., Lucero-Arce, A., MurilloAmador, B., and Troyo-Diéguez, E. 2003. Response to Salinity of Three Grain Legumes for Potential Cultivation in Arid Areas. Soil science and Plant Nutrition, 49(3): 329-336.

[18] Munns, R. 2002. Comparative Physiology of Salt and Water Stress. Plant, Cell and Environment, 25(2): 239-250.

[19] N. C. Turner. 1981. Techniques and Experiment Approaches for Measurement of Plant Water Status, Plant soil, Vol. 52, pp 339-366.

[20] Nyi, N., Sridokchan, W., Chai-arree, W., and Srinives, P. 2012. Nondestructive Measurement of Photosynthetic Pigments and Nitrogen Status in Jatropha (Jatropha curcas L.) by Chlorophyll Meter. The Philippine Agricultural Scientist, 95(2).

[21] Netondo, G. W., Onyango, J. C., and Beck, E. 2004. Sorghum and Salinity: Response of Growth, Water Relations, and Ion Accumulation to NaCI Salinity. Crop Science, 44(3): 797-805

[22] Parida, A. K., and Das, A. B. 2005. Salt tolerance and salinity effects on plants: a review. Ecotoxicology and environmental safety. 60(3): 324-349.

[23] Wei, Y., Xu, X., Tao, H., \& Wang, P. 2006. Growth performance and physiological response in the halophyte Lycium barbarum grown at salt-affected soil. Annals of applied biology, 149(3), 263-269.

[24] Zhao, G., Ma, B. L., and Ren, C. Z. 2007. Growth, Gas Exchange, Chlorophyll Fluorescence, and Ion Content of Naked Oat in Response to Salinity. Crop Science, 47(1): 123-131. 